\title{
EFFECTS OF CLIMATE CHANGE ON INCOME GENERATING ACTIVITIES OF FARMERS IN OSUN STATE, NIGERIA
}

\author{
AKINBILE, L. A. \\ Department of Agricultural Extension and Rural Development, \\ University of Ibadan \\ lakinbile@yahoo.com, la.akinbile@mail.ui.edu.ng \\ $+2348023250454$ \\ http://www.ui.edu.ng/LAAkinbile
}

\begin{abstract}
The need to examine the changes that the effect of climate change brings about on the income generating activities of farmers necessitated this study. Two local government areas (LGAs) were randomly selected and simple random sampling was used to sample 160 farmers from the 2 LGAs. Chi-square and Pearson products moment correlation (PPMC) were used to analyze the data obtained with the use of structured interview schedule. Results of the study show that there has been a reduction in the production of tree crops by respondents. Also, their exploitation of non-timber forest products such as snails and firewood has reduced. There has however been an increase in the involvement in trading activities by respondents. Also, more of them are now involved in the cultivation of potato. There exists a significant relationship between respondent' sex, primary occupation, perception of effect of climate change and the level of changes that have occurred in their income generating activities. Reasons adduced by respondents for the changes are perceived deforestation, changes in climatic conditions, soil degradation, land tenure system, inadequate storage and processing facilities, inadequate credit facilities and market price of agricultural activities. Extension should thus concentrate on activities in which more people are now involved as against the traditional ones that they used to cultivate.
\end{abstract}

Keywords: climate change, farming activities, non-timber forest products

\section{INTRODUCTION}

Change and long term variability of regional climate have been a natural process to which mankind was able to adjust in the past. But with increasing population and human activities, the greenhouse gases have risen beyond the natural level. Therefore, climate change and variability have been pushed beyond the natural limits that man can cope with. One of he global concerns is how to control the factors leading to climate change, but there is a dilemma. The major issue is that population will continue to rise and the increasing population must meet their needs for survival. It implies therefore that the vicious circle of human activities (agricultural and industrial), ecological degradation, emission of greenhouse gasses, global warming and climate change is a continuum. It is more worrisome that even if emissions of greenhouse gasses into the atmosphere were totally curtailed, the concentration of carbon dioxide, methane, and nitrous oxide in the atmosphere might lead to any years of persistent anomaly in the climate systems (IPCC, 2001).

The realities of anomalies in climate systems and climate change have been wit us since over three decades. Evidences of climate change have been documented and few examples are Louise and Rudy (1997), Karl and Knight (1998), Bello (1998), IPCC (2001), UNFCCC (2003). The various climate models have identified the indices of climate change to include a change in any or combinations of the following: surface albedo, annual mean temperature, mean temperature during the growing season, day/night temperature range, extreme seasonal temperatures, onset and cessation of the rains, rainfall seasonality and 
replicability of the mean rainfall regime, duration of the growing season and annual precipitation rates, as well as shift in rainfall belts (Bello, 2010).

The pattern of the general circulation of the atmosphere which determines the characteristics o global and regional climate will be different from what it is currently. If the current global warming persists unchecked, it may lead to significant changes in global and regional climates (Ayoade, 2010). The anticipated changes include the following: substantial increase in the length of the growing season in the middle and high altitudes, increase in precipitation extremes, giving rise to increase in the occurrences of floods and droughts, as well as loss of biodiversity and rare/valued ecosystems. These will affect agricultural production and land use, with crop pests and diseases being greatly influenced in their incidence, spread and distribution.

The present and projected impacts of global warming-induced climate change are not mostly beneficial. As a result, there is the need for attempts to be made at global and national levels to devise appropriate response strategies to tackle the problem. These have and should continue to be in the form of mitigation and adaptation measures. It is pertinent to note that trees in the forests have been reduced gradually without replacement, and this has affected the availability of various plants and animal species. Although there is increase in demand for them, the substantial effect of deforestation on the soil makes it exposed, while vegetation cover becomes thinner, and affects the fertility of the soil (Ayoade, 2010). This affects the income generating activities of farmers, forcing them to diversify to cultivation of other crops or even the adoption of different income generating activities. This study assessed the effects that climate changes has on the income generating activities of farmers in Osun State, which is gradually shifting from a forest region to being a derived savannah. The challenges that the changes has for extension delivery were also brought out.

\section{METHODOLOGY}

Structured questionnaire was used to collect data for the study. Two out of the 31 local government areas (LGAs) in Osun State were randomly selected through simple random sampling, to give Odo-Otin and Iwo LGAs. Two wards each were selected from the LGAs, making 4 wards. A village was selected from each of the selected wards to have 4 wards, from which 40 farmers were randomly selected from each to give a sample size 160. Changes in the income generating activities of farmers were assessed by asking them to respond to which of the 23 income generating activities (generated and validated through pretest) they were involved in 10 years ago and which ones they are involved in now. The percentage change in the two periods for each income generating activity was obtained.

\section{RESULTS}

\section{Personal characteristics of respondents}

Table 1 show that 60 percent of the respondents are within the ages of 40 and 60 years. This suggests that many of the respondents are in their active age when they can still effectively diversify their income generating activities. Only about 33 percent are above 60 years who are likely to be avast to income diversification. It also shows that 93.8 percent are males. The perception of seeing a farmer as only an adult male is still common in rural communities. The marital status of 85 percent of the respondents indicated that they were married and thus have the opportunity of deriving the support of their household members in carrying out their income generating activities. About half of the respondents are married, while the remaining are mostly Christians, with few of hem being traditional worshippers. 
Table 1: Respondents' personal characteristics

\begin{tabular}{|c|c|c|c|}
\hline \multicolumn{2}{|c|}{ Characteristics } & Frequency & Percentage \\
\hline \multirow{5}{*}{ Age (Years) } & $30-39$ & 11 & 6.9 \\
\hline & $40-49$ & 48 & 30.0 \\
\hline & $50-59$ & 48 & 30.0 \\
\hline & $60-69$ & 38 & 23.7 \\
\hline & 70 and above & 15 & 9.4 \\
\hline \multirow[t]{2}{*}{ Sex } & Male & 150 & 93.75 \\
\hline & Female & 10 & 6.25 \\
\hline \multicolumn{2}{|c|}{ Marital status Single } & 10 & 6.25 \\
\hline & Married & 136 & 85.0 \\
\hline & Divorced & 4 & 2.50 \\
\hline & Widowed & 2 & 1.25 \\
\hline \multirow[t]{3}{*}{ Religion } & Christianity & 82 & 51.2 \\
\hline & Islam & 68 & 42.50 \\
\hline & Traditional & 10 & 6.25 \\
\hline \multicolumn{4}{|l|}{ Education } \\
\hline \multicolumn{2}{|c|}{ No formal education } & 27 & 16.8 \\
\hline & Adult educ. & 33 & 21.6 \\
\hline & Pry school & 74 & 46.25 \\
\hline & Sec school & 16 & 10.0 \\
\hline & Post secondary & 10 & 6.3 \\
\hline
\end{tabular}

Only 16.8 percent of the respondents had no formal education. This indicated a high literacy rate among the respondents. Literacy has the tendency of exposing the respondents to information on climate change and its effect on income generating activities, especially farming. This may make them alive to the realities of their having to diversify to reduce the risks associated with it.

\section{Perceived effect of climate change among respondents}

It is indicated on Table 2 that 90 percent perceived the availability of trees as the greatest effect of climate change. Availability of non timber forest products (NTFPs) was perceived to be affected next by 89 percent of the respondents. Deforestation was indicated by 83.1 percent as the effect of climate change. This shows that climate change is perceived by respondents to have effect on farming, especially availability of trees, NTFPs and deforestation. This is in line with the position of Ayoade (2010) that climate change has undesirable effects on farming activities. The need to address the effects of climate change needs to consider how these activities would be addressed in order to help sustain the farming profession. 
Table 2: Perceived effect of climate change among respondents

\begin{tabular}{lllllll}
\hline Effects & $\begin{array}{l}\text { Agreement } \\
\text { Freq. }\end{array}$ & \% & $\begin{array}{l}\text { Indecision } \\
\text { Freq. }\end{array}$ & \% & $\begin{array}{l}\text { Disagreement } \\
\text { Freq. }\end{array}$ & \% \\
\hline $\begin{array}{l}\text { Soil } \\
\text { degradation/ }\end{array}$ & 94 & 58.8 & 14 & 8.8 & 52 & 32.5 \\
$\begin{array}{l}\text { loss of } \\
\text { fertility }\end{array}$ & & & & & \\
$\begin{array}{l}\text { Change in } \\
\text { farming }\end{array}$ & 113 & 70.6 & 12 & 7.5 & 35 & 21.9 \\
pattern & & & & & \\
$\begin{array}{l}\text { Deforestation } \\
\text { Change in }\end{array}$ & 92 & 83.1 & 11 & 6.9 & 16 & 10.0 \\
$\begin{array}{l}\text { land tenure } \\
\text { system }\end{array}$ & 57.5 & 7 & 4.4 & 61 & 38.1 \\
$\begin{array}{l}\text { Availability } \\
\text { of trees }\end{array}$ & 144 & 90.0 & 4 & & & \\
$\begin{array}{l}\text { Reduced } \\
\text { availability } \\
\text { of NTFPs }\end{array}$ & 12 & 89.0 & 3 & 2.5 & 12 & 7.5 \\
$\begin{array}{l}\text { Reduced } \\
\text { productivity }\end{array}$ & 74 & 46.3 & 22 & 2.0 & 15 & \\
\hline
\end{tabular}

Changes in respondents' income generating activities

Table 3 indicates that the activities in which involvement was reduced are cultivation of tree crops of cocoa and Kola, selling of firewood, collection of snails, lumbering and hunting, while those in which more people are now involved are trading and cultivation of annual cops. The percentage change for cultivation of cocoa was 23.8 percent, while that of kola was 21.9 percent. Percentage change for selling of firewood was 29.4 percent, which may be a reflection of the availability of firewood for sale as a result of deforestation. Hunting also had a percentage change of 15.6 percent, while collection of snail had a percentage change of 18.6, which may be indication of reduced availability of game. Trading had a percentage increase of 18.1. This suggests that more people are now drifting from farming and are now involved in trading activities. The result is a reflection of the fact that while climate change is negatively affecting cultivation of perennial crops and the exploitation of NTFPs, it is making more respondents cultivate annual crops and be more involved in trading activities. It is important that extension activities be sensitive about these diversifications by concentrating more on activities in which more of the farmers are now involved, that is, those income generating activities with positive percentage changes.

Table 3: Changes in respondents' income generating activities

\begin{tabular}{llllll}
\hline Activities & $\begin{array}{l}\text { Before } \\
\text { Freq. }\end{array}$ & \% & $\begin{array}{l}\text { Now } \\
\text { Freq. }\end{array}$ & \% & \% changes \\
\hline Cocoa & 90 & 56.3 & 52 & 32.5 & -23.8 \\
Kola & 98 & 61. & 63 & 39.4 & -21.9 \\
Potato & 133 & 83.1 & 146 & 9.3 & 8.1 \\
Yam & 141 & 88.1 & 141 & 88.1 & 0 \\
Maize & 149 & 93.1 & 157 & 98.1 & 5.0 \\
Cassava & 137 & 85.6 & 141 & 88.1 & 2.5 \\
$\begin{array}{l}\text { Rearing } \\
\text { sheep }\end{array}$ & 16 & 10.0 & 13 & 8.1 & -1.9
\end{tabular}




\begin{tabular}{|c|c|c|c|c|c|}
\hline $\begin{array}{l}\text { Rearing of } \\
\text { goat }\end{array}$ & 75 & 46.9 & 84 & 52.5 & -0.6 \\
\hline $\begin{array}{l}\text { Raising of } \\
\text { poultry }\end{array}$ & 75 & 46.9 & 45 & 28.1 & -1.9 \\
\hline Piggery & 3 & 1.9 & 2 & 1.3 & -0.6 \\
\hline Rabbitery & 3 & 1.9 & 3 & 1.9 & 0 \\
\hline $\begin{array}{l}\text { Collecting } \\
\text { snails }\end{array}$ & 58 & 36.3 & 28 & 17.5 & -18.8 \\
\hline $\begin{array}{l}\text { Collecting } \\
\text { fruits }\end{array}$ & 94 & 58.8 & 100 & 62.5 & 3.8 \\
\hline Fishing & 9 & 5.6 & 5 & 3.1 & -2.5 \\
\hline Hunting & 50 & 31.3 & 25 & 15.6 & -15.6 \\
\hline $\begin{array}{l}\text { Food } \\
\text { processing }\end{array}$ & 101 & 63.1 & 106 & 66.3 & 3.1 \\
\hline $\begin{array}{l}\text { Selling of } \\
\text { firewood }\end{array}$ & 75 & 46.9 & 28 & 17.5 & -29.4 \\
\hline $\begin{array}{l}\text { Food } \\
\text { vendoring }\end{array}$ & 14 & 8.8 & 9 & 5.6 & -3.1 \\
\hline Trading & 51 & 31.9 & 80 & 50.0 & 18.1 \\
\hline $\begin{array}{l}\text { Craft } \\
\text { basket } \\
\text { weaving }\end{array}$ & 28 & 17.5 & 23 & 14.4 & -3.1 \\
\hline Lumbering & 12 & 7.5 & - & - & -7.5 \\
\hline Artisan & 10 & 63 & 9 & 5.6 & -0.6 \\
\hline Hired labour & 9 & 5.6 & 1 & 0.6 & -5.0 \\
\hline
\end{tabular}

Reasons adduced by respondents for changes in the income generating activities

Results on Table 4 indicate that soil degradation, climatic variations and deforestation are the most indicated reasons for changes in the income generating activities recorded by respondents. It shows that soil degradation, a result of exposure of the soil to the vagaries of weather has serious effect on the income generating activities in which respondents were involved. Deforestation is also a significant factor as it also exposes the soil to climatic torture, while climatic variation affects the courses of crops, and thus the productivity attained by farmers. Efforts to assist farmers in improving their productivity must take these important factors into consideration.

Table 4: Reasons adduced for the changes

\begin{tabular}{|c|c|c|}
\hline Reasons & Frequency & Percentage \\
\hline Climatic variations & 133 & 83.1 \\
\hline Soil degradation & 149 & 93.1 \\
\hline Land tenure system & 94 & 58.8 \\
\hline Deforestation & 137 & 85.6 \\
\hline $\begin{array}{l}\text { Inadequate storage } \quad \& \\
\text { processing facilities }\end{array}$ & 51 & 31.9 \\
\hline Scarcity of inputs & 28 & 17.5 \\
\hline $\begin{array}{l}\text { Market price of agric } \\
\text { commodities }\end{array}$ & 75 & 46.9 \\
\hline Credit availability & 23 & 14.4 \\
\hline Labour availability & 45 & 28.1 \\
\hline
\end{tabular}




\section{Relationship between selected characteristics of respondents and changes in their income generating activities}

Table 5 shows that there exist a significant relationship between respondents' sex and the changes in their income generating activities. The males had more changes in their income generating activities than the females. Also, their primary occupation had significant relationship with the changes in the income generating activities they had. Those that had farming as their primary occupation had more changes than those that had farming as their secondary occupation. There was also a significant relationship between perceived effect of climate change among respondents and the change realized in their income generating activities. The contingency coefficient of 0.61 indicates a strong relationship between the two variables. This is in line with the position of Bello (2010) that farmers are coming to the effect of climate change on their activities in effort at achieving food security. Thus, those that had more favourable perception about the effect of climate change effected more changes in their income generating activities. There is thus the need that the effects of climate change that could be mitigated are so treated, while extension should concentrate more on the delivery of information about income generating activities in which the respondents are now more involved.

Table 5: Relationship between selected characteristics of respondents and changes in their income generating activities

\begin{tabular}{lllll}
\hline Variable & $\boldsymbol{\chi}^{2}$ & df & p value & cc \\
\hline Sex & 0.49 & 1 & $0.007^{*}$ & 0.24 \\
Marital status & 2.18 & 1 & 0.130 & 0.03 \\
Religion & 1.63 & 2 & 0.440 & 0.01 \\
$\begin{array}{l}\text { Primary occupation } \\
\text { Perceived effect of }\end{array}$ & 24.9 & 4 & $0.005^{*}$ & 0.39 \\
climate change & 0.25 & 1 & $0.001^{*}$ & 0.61 \\
\hline
\end{tabular}

* Significant at 0.01

Results of PPMC test showed that no significant relationship exist between respondents' age and the changes in their income generating activities. Thus, age has no effect on the income generating activities in which the respondents were involved.

\section{CONCLUSION}

It can be concluded from the findings of this study that many of the respondents are males and middle-aged. Also, most of them were married and had one form of formal education or the other. It can also be concluded that there has been a reduction in the production of tree crops by respondents. Also, their exploitation of non-timber forest products such as snails and firewood has reduced. There has however been an increase in the involvement in trading activities by respondents. There exists a significant relationship between the level of changes that have occurred in their income generating activities as well as their sex, primary occupation, perception of effect of climate change. Reasons adduced by respondents for the changes are perceived deforestation, changes in climatic conditions, soil degradation, land tenure system, inadequate storage and processing facilities, inadequate credit facilities and market price of agricultural activities. Extension should thus concentrate on activities in which more people are now involved as against the traditional ones that they used to cultivate. This will make extension services more proactive in addressing the needs of farmers in the face of the threatening climate change. 


\section{REFERENCES}

Ayoade, J. O (2010): Climate Change: Causes, Effects and Solution. Impact of climate change on food security in sub-Saharan Africa. Proceedings of the $14^{\text {th }}$ Annual Symposium of the International Association of Research Scholars and Fellows, IITA, Ibadan pp7-11

Bello, N. J (1998): Evidence o Climate Change based on Rainfall Records in Nigeria. Weather 53(12) 412-418

Bello, N. J (2010): Impact of Climate Change on Food Security in sub- Saharan Africa. Impact of climate change on food security in sub-Saharan Africa. Proceedings of the $14^{\text {th }}$ Annual Symposium of the International Association of Research Scholars and Fellows, IITA, Ibadan pp13-25

IPCC (Intergovernmental Panel on Climate Change, 2001): Climate Change: The Scientific Basis. Contribution of Working Group 1 on the Third Assessment Report of the IPCC, Cambridge University Press.

Karl, T. R and Knight, R. W (1998): Circular Trends of Precipitation Amount, Frequency and Intensity in the USA. Bulletin of the American Meteorological Society 79: 231-241

Louise, O. F and Rudy, R (1997): Keeping World Food Security on the Agenda: Implications for the United Nations and the CGIAR. Issues in Agriculture 11: 1-16

UNFCCC (United Nations Fund for Climate Change Convention, 2003): Caring for Climate: A Guide to Climate Change Convention and the Kyoto Protocol. Climate Change Secretariat, Bonn, Germany. 